\title{
Clinically abnormal case with paternally derived partial trisomy 8p23.3 to 8pI 2 including maternal isodisomy of 8p23.3: a case
} report

\author{
Dilek Aktas*1, Anja Weise ${ }^{2}$, Eda Utine ${ }^{1}$, Dursun Alehan ${ }^{3}$, Kristin Mrasek ${ }^{2}$, \\ Ferdinand von Eggeling ${ }^{2}$, Heike Thieme ${ }^{2}$, Ergul Tuncbilek ${ }^{1}$ and \\ Thomas Liehr ${ }^{2}$
}

\begin{abstract}
Address: ${ }^{1}$ Hacettepe University Faculty of Medicine, Department of Genetics, 06100 Sihhiye, Ankara, Turkey, ${ }^{2}$ Institut für Humangenetik und Anthropologie, Kollegiengasse 10, D-07743 Jena, Germany and ${ }^{3}$ Hacettepe University Faculty of Medicine, Department of Peditarics Cardiology, 06100 Sihhiye, Ankara, Turkey

Email: Dilek Aktas* - daktas@hacettepe.edu.tr; Anja Weise - aweise@mti.uni-jena.de; Eda Utine - geutine@hacettepe.edu.tr; Dursun Alehan - dalehan@ hacettepe.edu.tr; Kristin Mrasek - kmra@mti.uni-jena.de; Ferdinand von Eggeling - fegg@mti.uni-jena.de; Heike Thieme - Heike.thieme@med.uni-jena.de; Ergul Tuncbilek - etuncbil@hacettepe.edu.tr; Thomas Liehr - Thomas.Liehr@mti.uni-jena.de

* Corresponding author
\end{abstract}

Published: 30 June 2009

Molecular Cytogenetics 2009, 2:14 doi:10.1186/1755-8166-2-14
Received: 6 May 2009

Accepted: 30 June 2009

This article is available from: http://www.molecularcytogenetics.org/content/2/1//4

(c) 2009 Aktas et al; licensee BioMed Central Ltd.

This is an Open Access article distributed under the terms of the Creative Commons Attribution License (http://creativecommons.org/licenses/by/2.0), which permits unrestricted use, distribution, and reproduction in any medium, provided the original work is properly cited.

\begin{abstract}
Background: Because of low copy repeats (LCRs) and common inversion polymorphisms, the human chromosome $8 p$ is prone to a number of recurrent rearrangements. Each of these rearrangements is associated with several phenotypic features. We report on a patient with various clinical malformations and developmental delay in connection with an inverted duplication event, involving chromosome 8p.
\end{abstract}

Methods: Chromosome analysis, multicolor banding analysis (MCB), extensive fluorescence in situ hybridization (FISH) analysis and microsatellite analysis were performed.

Results: The karyotype was characterized in detail by multicolor banding (MCB), subtelomeric and centromere-near probes as 46,XY,dup(8)(pter->p23.3::p12->p23.3::p23.3->qter). Additionally, microsatellite analysis revealed the paternal origin of the duplication and gave hints for a mitotic recombination involving about $6 \mathrm{MB}$ in 8p23.3.

Conclusion: A comprehensive analysis of the derivative chromosome 8 suggested a previously unreported mechanism of formation, which included an early mitotic aberration leading to maternal isodisomy, followed by an inverted duplication of the $8 \mathrm{p} / 2 \mathrm{p} 23.3$ region.

\section{Background}

To date, a number of patients with inverted duplication of $8 p$ have been identified through cytogenetic analysis [1-7] and different breakpoints related to $8 \mathrm{p}$ have been reported [4]. The distal breakpoint was predominantly in 8 p23 and was found in combination with various proximal breakpoints (centromere, p11 and p12), but predominantly within $8 \mathrm{p} 11$. 


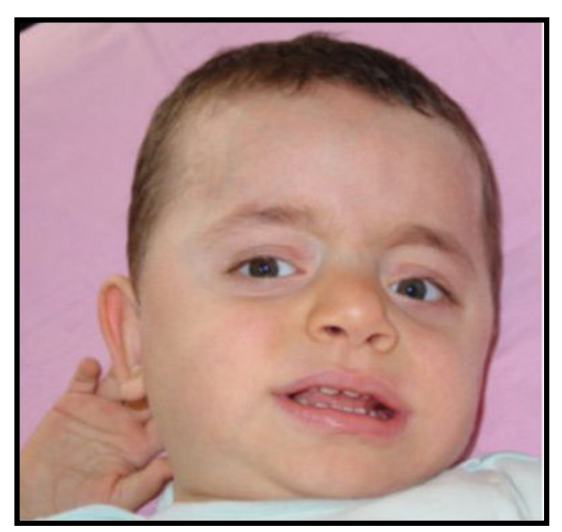

\section{Figure I}

Frontal view of the reported case at 15 months of age.
An inverted duplication of $8 \mathrm{p}$ is associated with mental retardation, distinct facial anomalies, agenesis of corpus callosum and hypotonia. Although less common, congenital heart defects, coloboma, scoliosis and seizures are noted.

We report another patient with a complex rearrangement leading to an inverted duplication of 8p23.3 to 8p12. Phenotypic findings in our patient and previously reported chromosome $8 \mathrm{p}$ inverted duplications are reviewed and several important features are highlighted.

\section{Case presentation Clinical details}

The male infant was the second child born to a non-consanguineous couple. Following a normal gestation and delivery, the boy was born at 40 -weeks of gestation with a birth weight of $3.2 \mathrm{~kg}$. There were no neonatal problems or feeding difficulty.

Table I: List of BAC probes used to confirm the presence of the duplication

\begin{tabular}{|c|c|c|c|c|}
\hline \multirow[t]{2}{*}{ FISH-probe } & \multirow[t]{2}{*}{ Chromosomal Location } & \multirow[t]{2}{*}{ Location in MB (NCBI 36.1) } & \multicolumn{2}{|c|}{ FISH-result } \\
\hline & & & \#8 & $\operatorname{der}(8)$ \\
\hline Subtelomere probe (Vysis) & $8 p 23$ & 0.55 & Ix & $\mathrm{Ix}$ \\
\hline RPII-29A2 & $8 p 23$ & $5.106-5.256$ & Ix & $2 x$ \\
\hline RP5-991O23 & $8 p 23$ & $5.342-5.459$ & Ix & $2 x$ \\
\hline CTD-2629116 & $8 p 23$ & $6.689-6.785$ & Ix & $2 x$ \\
\hline RPII-540E4 & $8 p 23$ & $8.029-8.179$ & Ix & $2 x$ \\
\hline RPII-2IIC9 & $8 p 23$ & $8.504-8.677$ & Ix & $2 x$ \\
\hline RPII-24IPI2 & $8 p 23$ & $9.788-9.958$ & Ix & $2 x$ \\
\hline RPII-I77H2 & $8 p 23$ & $10.696-10.796$ & Ix & $2 x$ \\
\hline RPII-589NI5 & $8 p 23$ & $11.740-11.803$ & Ix & $2 x$ \\
\hline RPII-433L7 & $8 p 22$ & $|4.316-| 4.46 \mid$ & Ix & $2 x$ \\
\hline RPII-60C8 & $8 p 22$ & $15.290-15.445$ & Ix & $2 x$ \\
\hline RPII-44LI8 & $8 p 22$ & $15.557-15.699$ & Ix & $2 x$ \\
\hline RPII-255EI3 & $8 p 22$ & $16.333-16.472$ & Ix & $2 x$ \\
\hline RPII-I9N2I & $8 p 22$ & $16.444-16.618$ & Ix & $2 x$ \\
\hline RPII-525O22 & $8 p 22$ & $17.846-17.950$ & Ix & $2 x$ \\
\hline bA64C22 - BAC-PAC Chori resource & $8 p \mid 1.21$ & n.a. & Ix & Ix \\
\hline
\end{tabular}

If not indicated differently the probes were derived from Dr. W.W. Cai, Baylor College, Houston, Texas, USA. 
Table 2: List of used microsatellite probes and results obtained for mother, father and child

\begin{tabular}{|c|c|c|c|c|c|c|}
\hline Marker & Chromosomal location & Location in MB (NCBI build 36.1) & Mother & Father & Child & Result \\
\hline D8S264 & $8 p 23$ & 2.14 & ac & bb & $\mathrm{ccc}$ & mat. UPD \\
\hline D8S 1099 & $8 p 23$ & 6.04 & bb & aa & bbb & mat. UPD \\
\hline D8SII30 & $8 p 22$ & 11.80 & $a b$ & bc & $\mathrm{bb}$ & n.i. \\
\hline D8SII06 & $8 p 22$ & $|2.8|$ & $a b$ & $a b$ & $a b$ & n.i. \\
\hline D8SII45 & $8 p 22$ & 18.40 & bc & $a b$ & bbc & paternal \\
\hline D8SI477 & $8 p 12$ & 32.08 & $a b$ & cc & acc & paternal \\
\hline D8SIIIO & $8 q 11$ & 53.29 & bb & $a b$ & $b b$ & n.i. \\
\hline D8SIII3 & $8 q 12$ & 59.85 & ac & bd & ad & $\mathrm{i} / \mathrm{n}$ \\
\hline D8SIII9 & $8 q 21$ & 87.33 & $a b$ & $a b$ & $a b$ & n.i. \\
\hline D8SII32 & $8 q 23$ & 107.40 & $\mathrm{cc}$ & $a b$ & bc & $\mathrm{i} / \mathrm{n}$ \\
\hline D8SII 28 & $8 q 24$ & 128.65 & ac & $a b$ & bc & $\mathrm{i} / \mathrm{n}$ \\
\hline D8S373 & $8 q 24$ & $143.9 \mid$ & bd & ac & ad & $\mathrm{i} / \mathrm{n}$ \\
\hline
\end{tabular}

Abbreviations: $\mathrm{a}, \mathrm{b}, \mathrm{c}=$ type of alleles, mat. UPD = maternal uniparental disomy, n.i. $=$ non informative; i.n. $=$ informative normal.

At 15 months of age, his weight was $11.3 \mathrm{~kg}$ (10th-25th centiles), length was $87 \mathrm{~cm}$ (90th-95th centiles), and head circumference was $48 \mathrm{~cm}$ (10th-25th centiles). He

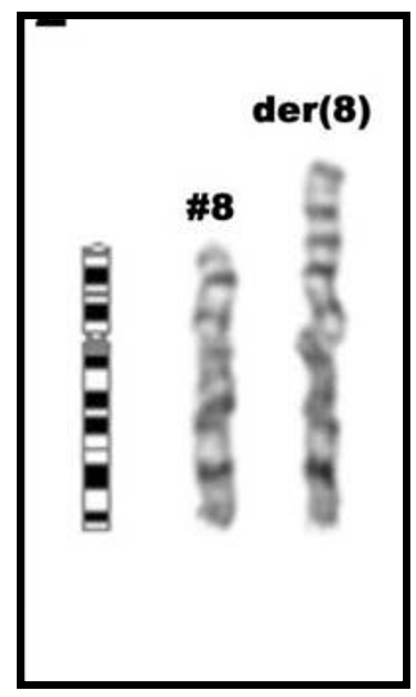

Figure 2

GTG-banding result showing only the normal (\#8) and the aberrant chromosome 8 of the present case, accompanied by an ideogram of a normal chromosome 8 . was evaluated for motor and language delay. Dysmorphic facial features including brachycephaly, prominent forehead, prominent nasal bridge, flared alae nasi, wide mouth with thin upper lip were present (Figure 1). Ears were large and posteriorly rotated. He had no eye or skeletal abnormalities. There was mild generalized hypotonia. He was still unable to sit and walk. He could roll on both sides, transfer objects hand-to-hand, but he could not use a spoon or fork for self-feeding.

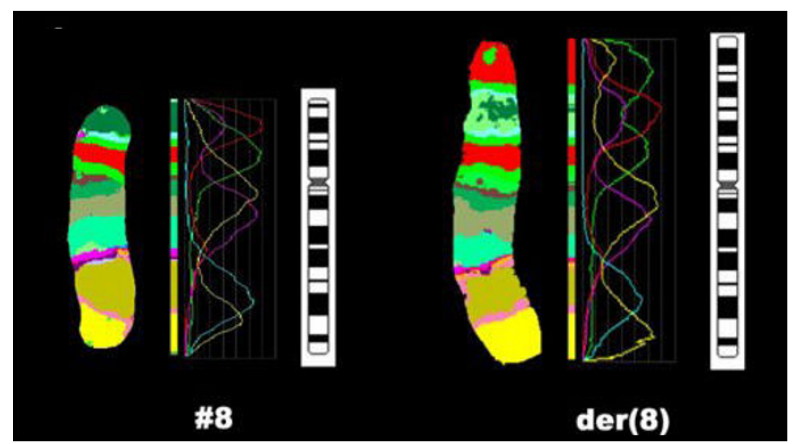

Figure 3

Result of multicolor banding (MCB) shows the MCBpseudo-coloring, the fluorochrome-profiles and the GTG-ideogram of the normal and the derivative chromosome 8. 


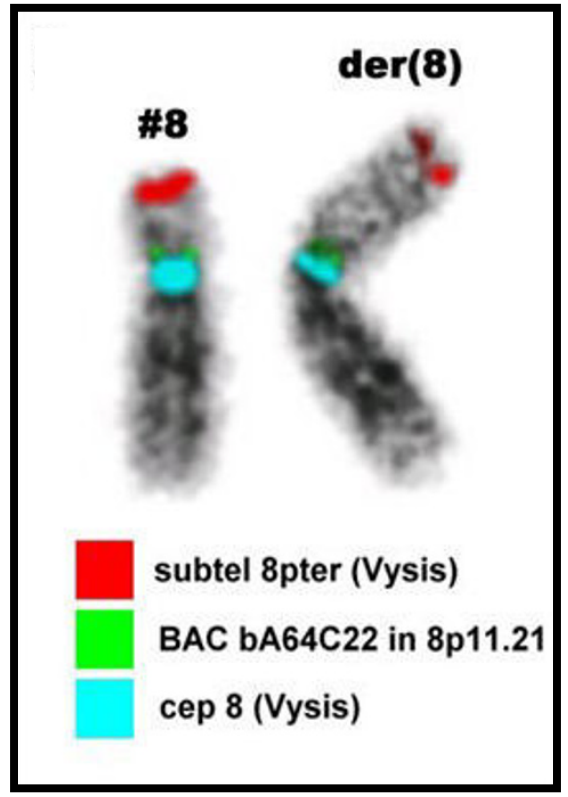

Figure 4

The normal and the aberrant chromosome 8 of the present case are depicted in inverted DAPI. A centromeric probe (blue), a centromere-near probe (green) and a subtelomeric probe (red) were hybridized together and revealed a more complex nature of the rearrangement.

An abdominal ultrasound was normal. Two-dimensional echocardiogram revealed small muscular ventricular septal defect. Brain MRI demonstrated agenesis of corpus callosum.

\section{Methods}

Karyotyping was performed on metaphase spreads prepared from peripheral blood lymphocytes by conven-

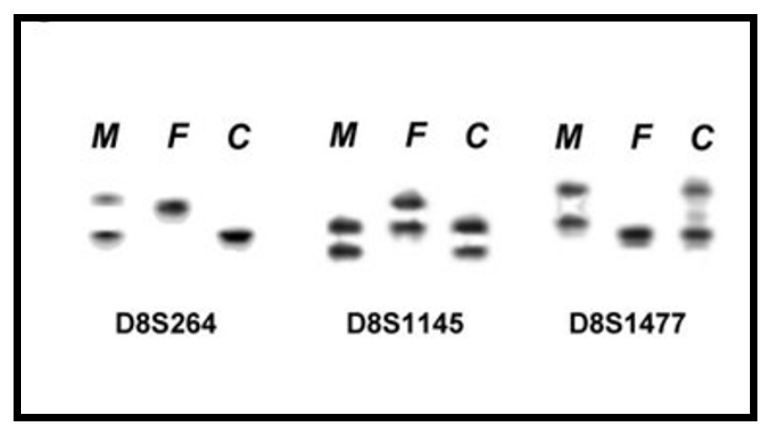

\section{Figure 5}

Three examples of the microsatellite anlysis result are shown. For the markers D8S264, D8SI I45 and D8SI477 the different alleles are shown for the mother $(M)$, the father $(F)$ and the child $(C)$. For result interpretation see Tab. 2.

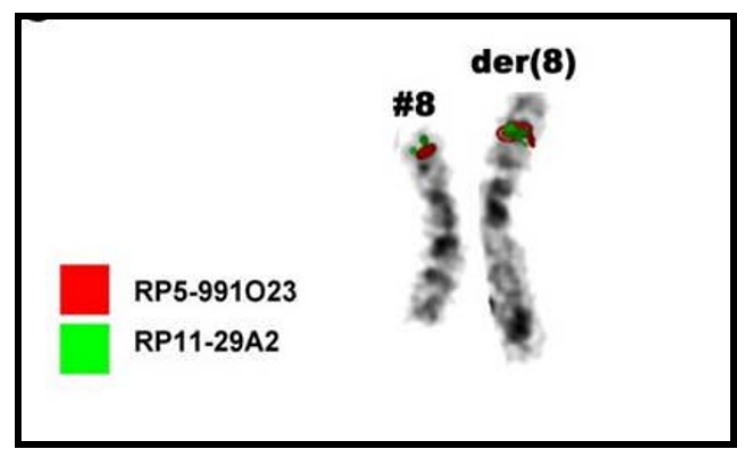

Figure 6

The normal and the aberrant chromosome 8 of the present case are depicted in inverted DAPI. In summary, the presence of three copies of the probes RPI I-29A2 (green) and RP5-99IO23 (red) could be proven by FISH.

tional methods. The aberrant karyotype was further studied applying multicolor banding (MCB) probe sets for chromosome 8 [8]; MCB-results were evaluated using the software of MetaSystems (Altlussheim, Germany) as previously described [9]. Moreover, a centromeric probe for chromosome 8 (Vysis), a subtelomeric probes for chromosome 8pter (Vysis), ), a centromere-near probe in 8p11.21 (bA64C22 - BAC-PAC Chori resource) and the BAC-probes listed in Table 1 were used. The latter were kindly provided by Dr. W.W. Cai, Baylor College, Houston, Texas, USA.

Microsatellite analysis was done as previously described [10] using the markers listed in Table 2.

\section{Results}

GTG-banded chromosome preparations were suggestive of duplication in 8p (Figure 2). The karyotype was characterized in detail using MCB (Figure 4), subtelomeric and centromere-near probes (Figure 3). The examinations indicated an inverted duplication involving segment $8 \mathrm{p} 12 \rightarrow 8 \mathrm{p} 23.3$, and the karyotype was re-interpreted as 46,XY,dup (8)(pter->p23.3::p12->p23.3::p23.3->qter).

The subtelomeric region on $8 \mathrm{p}$ was not deleted and the karyotype represented partial trisomy 8p23.3 to 8p12. Chromosome analysis of both parents revealed normal results, with no indication of a rearrangement in $8 \mathrm{p}$.

Microsatellite analysis (Figure 6) gave hints for an inverted duplication of the paternally derived chromosome 8 (markers D8S11145 and D8S1477 in Table 2). However, only maternal alleles could be observed for the markers D8S264 and D8S1099, both located in position 2.14 and $6.04 \mathrm{Mb}$ according to NCBI build 36.1. A deletion of the corresponding region could have been an explanation for this finding, however, FISH using the 


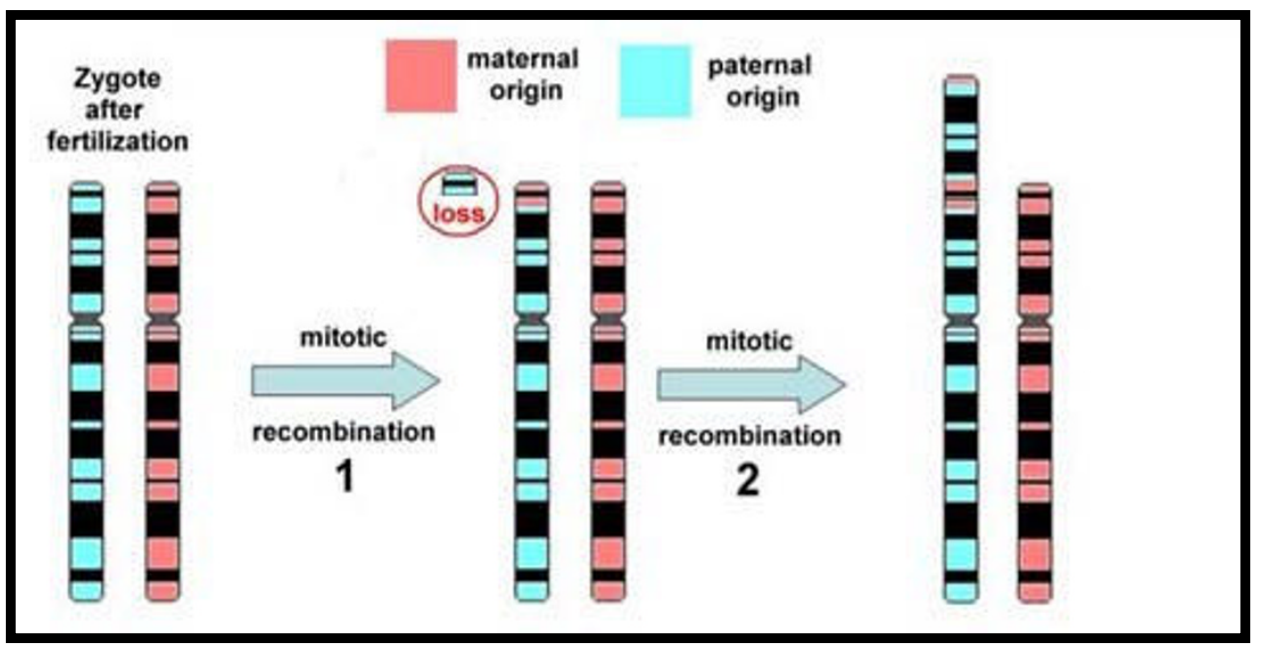

Figure 7

Suggested mode of formation of the derivative chromosome 8 of the present case.

three probes RP11-29A2, RP5-991O23 and CTD-2629I16 located in 5.2, 5.4 and $6.6 \mathrm{Mb}$, respectively, could not confirm this possibility (see Figure 5). Thus, a mitotic recombination of maternally and paternally derived chromosomes 8 , involving a loss of the paternally derived region 8p23.3 must have appeared prior to the building of the inverted duplication (Figure 7).

\section{Discussion}

Several studies have shown that particular subset of segmental duplications such as the olfactory receptor (OR) gene clusters are the substrate for the formation of intrachromosomal rearrangements involving the short arm of chromosome 8 . At the OR gene cluster, an intersister chromatid recombination [11] and an interhomologous chromatid ectopic recombination [12] event have been proposed for chromosome rearrangements of $8 \mathrm{p}$. The inv dup (8) consistently originate in maternal meiosis [12] and all the mothers of subjects with inv dup (8p) are heterozygous for an inversion polymorphism, present in $26 \%$ of normal controls, between the OR gene clusters $[11,12]$. Furthermore, polymorphic marker analysis also indicated that inv dup (8p) was partially heterodisomic indicating that two copies of maternal allele were present [13]. In our report, microsatellite analyses revealed the paternal origin of the duplication and gave hints for a mitotic recombination involving about $6 \mathrm{Mb}$ in $8 \mathrm{p} 23.3$. The mode of formation of the derivative chromosome 8 in the present patient was suggested as loss of paternally derived region 8 p23.3 and recombination of maternally and paternally derived chromosome 8 (Figure 7)

We report on an inverted duplication of region 8 p12 $\rightarrow 23.3$ presenting with significant motor develop- ment delay, hypotonia, facial dysmorphisms, ventricular septal defects and corpus callosum agenesis, most of which were reported in previous studies [4-7,11]. The regions 8p21 and 8p22 were commonly duplicated in all patients with inv dup (8p). Though different breakpoint regions for inv dup (8p) are reported, the clinical findings are quite homogeneous. In our report, however, the subtelomeric region was not deleted. We propose that the phenotypic findings of these patients are mainly due to trisomy 8 p $12 \rightarrow 23.3$ with an inverted duplication of $8 \mathrm{p}$. Recently, a duplication of 8p23.1 and triplication of 8p23.2 in patients affected by mental retardation and minor facial dysmorphisms have been presented [14].

A limited number of patients with inv dup 8p have so far been reported in the literature should not lead us to the conclusion that this duplication occurs extremely rare; it is more likely that it is rarely reported because of relatively non-specificity of the abnormalities in these patients and the cytogenetic band assignment by conventional cytogenetic analysis is difficult. The application of MCB demonstrates the occurrence of different inverted duplications within the short arm of chromosome 8 .

\section{Conclusion}

Inverted duplications on chromosome $8 \mathrm{p}$ are observed more frequently by the aim of technical improvement in routine cytogenetics. More complex karyotypes are being delineated by widely available use of newly developed tools. In conclusion, the present patient suggests that there might be a certain predisposition to chromosome $8 \mathrm{p}$ for more complex aberrations other than inverted duplications, which should be considered during the cytogenetic evaluation. 


\section{Competing interests}

The authors declare that they have no competing interests.

\section{Authors' contributions}

DA: carried out clinical examination, cytogenetic studies, drafted the manuscript; AW: carried out MCB analysis; EU: carried out clinical evaluation; DA: carried out cardiological evaluation; KM: carried out molecular genetic studies; FVE; carried out clinical evaluation; HT: carried out MCB analysis; ET: carried out clinical evaluation; TL: carried out molecular genetic studies and drafted the manuscript.

All the authors read and approved the final manuscript.

\section{Consent Section}

Written informed consent was obtained from the patient for publication of this case report and any accompanying images. A copy of the written consent is available for review by the Editor-in Chief of this journal.

\section{Acknowledgements}

We would like to thank to the family who participated in this study. This work was supported parts by the Ernst-Abbe-Stiftung and the Evangelische Studienwerk e.V. Villigst. The BAC probes listed in Table I were a generous gift of Dr. W.W. Cai, Baylor College, Houston, Texas, USA.

\section{References}

I. Yenamandra A, Perrone R, McLaughlin J, Mehta L: Inverted duplication/deletion of chromosome 8p: mild clinical phenotype. Am J Med Genet 1999, 82(I):91-3.

2. Fan YS, Siu VM: Molecular cytogenetic characterization of a derivative chromosome 8 with an inverted duplication of 8p21.3-->p23.3 and a rearranged duplication of 8q24.13--> qter. Am J Med Genet 200I, I 02(3):266-7I.

3. Tonk VS, Wilson GN, Velagaleti GV: Duplication 8 [inv dup(8)(pI2p23)] with macrocephaly. Ann Genet 200I, 44(4): $195-9$.

4. Pabst B, Arslan-Kirchner M, Schmidtke J, Miller K: The application of region-specific probes for the resolution of duplication $8 \mathrm{p}$ : a case report and a review of the literature. Cytogenet Genome Res 2003, 103(I-2):3-7.

5. Cooke SL, Northup JK, Champaige NL, Zinser W, Edwards PA, Lockhart LH, Velagaleti GV: Molecular cytogenetic characterization of a unique and complex de novo 8p rearrangement. $\mathrm{Am} J$ Med Genet A. 2008, I 46A(9): I | 66-1 I 72.

6. Glancy M, Barnicoat A, Vijeratnam R, de Souza S, Gilmore J, Huang S, Maloney VK, Thomas NS, Bunyan DJ, Jackson A, Barber JC: Transmitted duplication of 8p23.1-8p23.2 associated with speech delay, autism and learning difficulties. Eur J Hum Genet 2009, I 7(I):37-43.

7. Buysse K, Antonacci F, Callewaert B, Loeys B, Fränkel U, Siu V, Mortier G, Speleman F, Menten B: Unusual 8p inverted duplication deletion with telomere capture from 8q. Eur J Med Genet 2009, 52(I):3I-6.

8. Liehr T, Heller A, Starke H, Rubtsov N, Trifonov V, Mrasek K, Weise A, Kuechler A, Claussen U: Microdissection based high resolution multicolor banding for all 24 human chromosomes. Int J Mol Med 2002, 9(4):335-9.

9. Chudoba I, Plesch A, Lorch T, Lemke J, Claussen U, Senger G: High resolution multicolor-banding: a new technique for refined FISH analysis of human chromosomes. Cytogenet Cell Genet 1999, 84(3-4): 156-60.

10. Starke H, Schreyer I, Kähler C, Fiedler W, Beensen V, Heller A, Nietzel A, Claussen U, Liehr T: Molecular cytogenetic characterization of a prenatally detected supernumerary minute marker chromosome 8. Prenat Diagn 1999, 19(12):1169-74.
II. Giglio S, Broman KW, Matsumoto N, Calvari V, Gimelli G, Neumann T, Ohashi H, Voullaire L, Larizza D, Giorda R, Weber JL, Ledbetter $\mathrm{DH}$, Zuffardi O: Olfactory receptor-gene clusters, genomicinversion polymorphisms, and common chromosome rearrangements. Am J Hum Genet 200I, 68(4):874-83.

12. Floridia G, Piantanida M, Minelli A, Dellavecchia C, Bonaglia C, Rossi $\mathrm{E}$, et al:: The same molecular mechanisms at the maternal meiosis I produces mono- and dicentric 8p duplications. Am J Hum Genet 1996, 58:785-96.

13. Vermeesch JR, Thoelen R, Salden I, Raes M, Matthijs G, Fryns JP: Mosaicism del(8p)/inv dup(8p) in a dysmorphic female infant: a mosaic formed by a meiotic error at the $8 p$ OR gene and an independent terminal deletion event. J Med Genet 2003, 40(8):e93.

14. Giorda R, Ciccone R, Gimelli G, Pramparo T, Beri S, Bonaglia MC, Giglio S, Genuardi M, Argente J, Rocchi M, Zuffardi O: Two classes of low-copy repeats comediate a new recurrent rearrangement consisting of duplication at 8 p23.I and triplication at 8p23.2. Hum Mutat 2007, 28(5):459-68.
Publish with Biomed Central and every scientist can read your work free of charge

"BioMed Central will be the most significant development for disseminating the results of biomedical research in our lifetime. "

Sir Paul Nurse, Cancer Research UK

Your research papers will be:

- available free of charge to the entire biomedical community

- peer reviewed and published immediately upon acceptance

- cited in PubMed and archived on PubMed Central

- yours - you keep the copyright

Submit your manuscript here:

http://www.biomedcentral.com/info/publishing_adv.asp
BioMedcentral 